\title{
RESEARCH DESIGN FORMATION TO DETERMINE QUALITY INDICATORS OF POTENTIAL API, 2. QUALITY RISKS ARISING IN THE PROCESS OF SCALING THE SYNTHESIS PROCEDURE
}

\author{
N. Bevz, V. Mishchenko, V. Khomenko, V. Georgiyants
}

\begin{abstract}
Within the framework of the current pharmaceutical legislation, harmonized as much as possible with the EU and the USA to ensure the import / export of high-quality medicines (within the framework of the ICH and the positions of the global pharmaceutical sector), the transfer of technology for obtaining an active pharmaceutical ingredient requires taking into account many factors. Particular attention should be paid to identifying and eliminating risks that may arise when transferring a compound synthesis procedure to an industrial site. The scaling up of the synthesis procedure is accompanied by risks that can affect the quality of the final product, its safety and effectiveness.
\end{abstract}

The aim. The aim of this work is to summarize information regarding the emergence of risks that may arise when scaling the method of synthesis of active biological substances and quality control methods that allow avoiding the emergence of risks in production, studying stability and further application in medical practice.

Materials and methods. To carry out the research, we used the collection and analysis of data presented in modern scientific literature and documents of regulatory bodies and the results of our own experimental studies. With the help of FMEA analysis, the stages of scaling of the synthesis technique are identified, which are the most critical, and appropriate measures are proposed to reduce them. Based on the results of a survey of experts in the field of organic synthesis and pharmaceutical production, an appropriate matrix was drawn up and the priority number of risks was calculated according to three criteria: the severity of the consequences, the likelihood of influencing the stages of scaling up the synthesis method, and the degree of probability of detecting a hazard.

Results. The risks arising from changes in the synthesis technology during the transfer of a laboratory procedure to a pilot and/or industrial site (simplification of the synthesis scheme, use of reagents and solvents of a different purity class, replacement of a compound isolation method, etc.) have been identified and can affect the pharmacological action, efficiency, safety and storage conditions of biologically active substances. On the basis of risk analysis, it is proposed to use quality control techniques that allow avoiding these risks in the future in the production of a biologically active compound.

Conclusions. The stages of scaling up the methodology for the synthesis of a potential active compound for transfer to clinical and preclinical trials are determined, the reasons for the emergence of risks that must be taken into account in the industrial synthesis of BAS, the development of quality control methods and the preparation of an appropriate "certificate of quality" for a new biologically active compound are considered

Keywords: active substance, scaling up of the synthesis method, risks, standardization, quality control methods

Copyright (C) 2020, N. Bevz, V. Mishchenko, V. Khomenko, V. Georgiyants.

This is an open access article under the CC BY license (http://creativecommons.org/licenses/by/4.0).

\section{Introduction}

The introduction of new biologically active compounds in pharmaceutical practice begins with the study of the structure, physicochemical and biological properties of the substance. It is proposed to formulate mandatory requirements for the standardization of firstsynthesized substances during their transfer for primary pharmacological screening using a set of physicochemical studies, which are summarized by the development of a "quality certificate" of the test compound [1].

The next step in the introduction of new biologically active substances (BAS) into medical practice is the transfer of a compound to preclinical and clinical trials, which requires a sufficient amount of the substance to be tested. Sufficient BAS for further pharmacological tests is more often obtained by transferring the synthesis technique to a pilot/industrial site of pharmaceutical companies, which may be accompanied by a number of changes in the properties of the active substance.

Regulation of technology transfer in the pharmaceutical sector of Ukraine is associated with the creation of new high-tech products, improving the quality and consumer properties of pharmaceutical products, reducing costs, optimizing the use of resources of domestic origin, increasing the efficiency of pharmaceutical products and its quality [2 (part 2 of article 6)]. 
Strict requirements are set for the process of scaling the BAS synthesis technique, as the quality of the final product depends on its implementation [3-5]. This stage involves the identification and elimination of risks [6], as well as the introduction, according to the results, to the methods of quality control of critical parameters that may arise in the future $[6,7]$.

For the method of synthesis of compounds in industrial conditions choose companies that develop and implement original drugs, as well as work on the terms of commercialization, i. e. the manufacture of active pharmaceutical ingredient - generics on their own technological basis [8, 9]. In Ukraine, such corporations are "Farmak", "Interchem", PJSC SIC "Borshchahivskiy CPP", State Plant for Chemical Reagents Scientific and Technological Complex "Institute for Single Crystals", State Scientific Institution "Institute for Single Crystals", etc. The laboratory method of compound synthesis is transferred to the selected industrial site, which is previously improved or processed taking into account the capacity of the enterprise $[10,11]$.

The aim of the study is to summarize information on the risks that may arise during the scaling of methods of synthesis of active biological substances and quality control methods that avoid risks during production, study of stability and further application in medical practice.

\section{Planning (methodology) of the research}

The transfer of new synthesized BAS to preclinical and clinical pharmacological studies leads to the need to scale the synthesis technique. Scaling of the synthesis technique occurs in several stages and consists of increasing the yield of the final product in the laboratory, improving and transferring the technique to the pilot and then to the industrial site and standardization of each stage of the transfer of the synthesis technique.

At the stage of scaling the synthesis method, it is advisable to identify critical points in the technological scheme, confirm the physicochemical properties and stability of the substance and develop quality control techniques that will not only assess the identity of the substance, its purity and quantitative content, but also to select control points in the technological scheme of obtaining the compound. To further create a dossier for the active substance and registration of the drug, quality control methods are developed using pharmacopoeial methods of analysis.

The main stages of the transfer of the synthesis technique, at which there are risks that may affect the quality of the new biologically active compound, can be identified as follows:

1. Improving the method of synthesis of a new potential biologically active compound.
2. Making changes to the method of synthesis according to the capacity of the enterprise to ensure stable quality indicators.

3. Establishment of the properties of the obtained synthesized compound after change/improvement/scaling of the synthesis method and their harmonization with pharmacopoeial quality requirements.

4. Estimates of purity and quantitative content of potential BAS.

5. Development and formation of quality control methods taking into account all the risks that may affect the effectiveness and safety of the active compound.

\section{Materials and methods}

Legislative act regulating the quality control of medicines in Ukraine at all stages of production, release, storage, etc. - the Law of Ukraine "On Medicines". Regulation of technology transfer in the pharmaceutical sphere of Ukraine - the Law of Ukraine "On state regulation of activities in the field of technology transfer" (part 2, article 6).

To perform research according to the formed methodology, the collection and analysis of data presented in the modern scientific literature and regulatory documents (ICH [3], State Pharmacopoeia of Ukraine [12], European Pharmacopoeia [13], USP Pharmacopoeia [14], guidelines ST-N MOH) 42-3.5: 2016 "Medicines. Process validation" harmonized with EMA/CHMP/ CVMP/ QWP/BWP/70278/2012-Rev 1 [15] quality guidelines for production, distribution, storage, pre-clinical and clinical trials drugs $[16,17]$.

FMEA analysis revealed the stages of scaling the synthesis technique, which are the most critical, and proposed appropriate measures to reduce them. According to a survey of experts in the field of organic synthesis and pharmaceutical production, an appropriate matrix was compiled and the priority number of risks was calculated according to three criteria: severity of consequences, probability of impact on the scalability of synthesis methods and probability of risk detection.

To eliminate the risks of the production process of synthesis of biologically active substances, a complex risk indicator was calculated - the priority risk number (PRN) according to the formula:

$\mathrm{PRN}=\mathrm{S} \cdot \mathrm{O} \cdot \mathrm{D}$,

where $\mathrm{S}$ - significance of potential risk;

$\mathrm{O}$ - probability of risk;

$\mathrm{D}$ - probability of risk detection.

The absolute and relative value of PRN of the main stages of scaling the method of synthesis and standardization of the synthesized biologically active compound are given in Table 1 . 
Assessment of the occurrence, significance and identification of risks when scaling the method of BAS synthesis

\begin{tabular}{|c|c|c|c|c|c|c|c|c|}
\hline $\begin{array}{l}\text { Controlled } \\
\text { indicator }\end{array}$ & $\begin{array}{l}\text { Consequences of } \\
\text { non-compliance }\end{array}$ & $\begin{array}{l}\text { Diffi- } \\
\text { culty }\end{array}$ & Reason & $\begin{array}{l}\text { Prob- } \\
\text { ability }\end{array}$ & $\begin{array}{l}\text { Detection } \\
\text { method }\end{array}$ & $\begin{array}{l}\text { Difficul- } \\
\text { ty of } \\
\text { detection } \\
\end{array}$ & PRN & $\%$ \\
\hline 1 & 2 & 3 & 4 & 5 & 6 & 7 & 8 & 9 \\
\hline \multicolumn{9}{|c|}{ Improving the method of synthesis of a new potential biologically active compound } \\
\hline $\begin{array}{l}\text { One-stage synthesis } \\
\text { scheme }\end{array}$ & $\begin{array}{l}\text { The yield of the reac- } \\
\text { tion product }\end{array}$ & 1 & $\begin{array}{l}\text { Personnel er- } \\
\text { rors, malfunc- } \\
\text { tion of measur- } \\
\text { ing equipment }\end{array}$ & 2.50 & $\begin{array}{l}\text { Monitoring, } \\
\text { calibration } \\
\text { of equip- } \\
\text { ment }\end{array}$ & 2.25 & 5.63 & 1.29 \\
\hline $\begin{array}{l}\text { Two-stage synthe- } \\
\text { sis scheme }\end{array}$ & $\begin{array}{l}\text { The yield of the reac- } \\
\text { tion product, the occur- } \\
\text { rence of impurities }\end{array}$ & 2 & $\begin{array}{l}\text { Personnel er- } \\
\text { rors, malfunc- } \\
\text { tion of measur- } \\
\text { ing equipment }\end{array}$ & 2.50 & $\begin{array}{l}\text { Monitoring, } \\
\text { calibration } \\
\text { of equip- } \\
\text { ment }\end{array}$ & 2.50 & 12.50 & 2.87 \\
\hline $\begin{array}{l}\text { Multi-stage synthe- } \\
\text { sis scheme }\end{array}$ & $\begin{array}{l}\text { Reducing the yield of } \\
\text { the reaction product, } \\
\text { increasing the amount } \\
\text { of impurities }\end{array}$ & 4.5 & $\begin{array}{l}\text { Personnel er- } \\
\text { rors, malfunc- } \\
\text { tion of measur- } \\
\text { ing equipment }\end{array}$ & 4 & $\begin{array}{l}\text { Monitoring, } \\
\text { calibration } \\
\text { of equip- } \\
\text { ment } \\
\end{array}$ & 2.50 & 45.00 & 9.93 \\
\hline \multicolumn{9}{|c|}{ Making changes to the method of synthesis according to the capacity of the enterprise to ensure stable quality indicators } \\
\hline $\begin{array}{l}\text { Purity of starting } \\
\text { materials and sol- } \\
\text { vents }\end{array}$ & $\begin{array}{l}\text { Reduction of the yield } \\
\text { of the reaction product, } \\
\text { the occurrence of impu- } \\
\text { rities }\end{array}$ & 4.5 & Personnel errors & 2.75 & $\begin{array}{l}\text { Monitoring, } \\
\text { quality } \\
\text { control of } \\
\text { starting } \\
\text { materials } \\
\end{array}$ & 1 & 12.38 & 2.84 \\
\hline $\begin{array}{l}\text { Technological } \\
\text { parameters of } \\
\text { synthesis (tempera- } \\
\text { ture, pressure, time) }\end{array}$ & $\begin{array}{l}\text { Reduction of the yield } \\
\text { of the reaction product, } \\
\text { the occurrence of impu- } \\
\text { rities }\end{array}$ & 4.75 & $\begin{array}{l}\text { Personnel er- } \\
\text { rors, equipment } \\
\text { failure }\end{array}$ & 2.5 & $\begin{array}{l}\text { Monitoring, } \\
\text { calibration } \\
\text { of equip- } \\
\text { ment }\end{array}$ & 1.5 & 17.81 & 4.08 \\
\hline $\mathrm{pH}$ of the medium & $\begin{array}{l}\text { Reduction of the yield } \\
\text { of the reaction product, } \\
\text { the occurrence of impu- } \\
\text { rities }\end{array}$ & 4.75 & $\begin{array}{l}\text { Personnel er- } \\
\text { rors, equipment } \\
\text { failure }\end{array}$ & 2.75 & $\begin{array}{l}\text { Monitoring, } \\
\text { calibration } \\
\text { of equip- } \\
\text { ment } \\
\end{array}$ & 2.75 & 35.92 & 8.24 \\
\hline $\begin{array}{l}\text { Crystallization of } \\
\text { the substance }\end{array}$ & $\begin{array}{l}\text { Reduction of the yield } \\
\text { of the reaction product }\end{array}$ & 2.75 & & 2.5 & & 3 & 20.63 & 4.73 \\
\hline $\begin{array}{l}\text { Double crystalliza- } \\
\text { tion of the com- } \\
\text { pound }\end{array}$ & $\begin{array}{l}\text { Reduction of the yield } \\
\text { of the reaction product }\end{array}$ & 4.5 & & 2.5 & & 3 & 33.75 & 7.74 \\
\hline $\begin{array}{l}\text { Microbiological } \\
\text { purity }\end{array}$ & $\begin{array}{c}\text { Non-compliance with } \\
\text { specifications }\end{array}$ & 4.75 & & 1.75 & & 3 & 24.94 & 5.72 \\
\hline MQC compliance & $\begin{array}{c}\text { Non-compliance with } \\
\text { specifications }\end{array}$ & 3.5 & & 1 & & 1 & 3.5 & 0.80 \\
\hline \multicolumn{9}{|c|}{$\begin{array}{l}\text { Establishing the properties of the obtained synthesized compound during scaling of the synthesis method and harmoniza- } \\
\text { tion with pharmacopoeial quality requirements }\end{array}$} \\
\hline $\begin{array}{l}\text { Study of physical } \\
\text { constants of sub- } \\
\text { stances (description, } \\
\text { solubility, melting } \\
\text { point, boiling point, } \\
\text { solidification, etc.) }\end{array}$ & $\begin{array}{l}\text { Non-compliance with } \\
\text { specifications } \\
\text { Use of pharmacopoeial } \\
\text { methods and tests }\end{array}$ & 3 & $\begin{array}{l}\text { Personnel er- } \\
\text { rors, equipment } \\
\text { failure }\end{array}$ & 1 & $\begin{array}{l}\text { Monitoring, } \\
\text { calibration } \\
\text { of equip- } \\
\text { ment, } \\
\text { substance } \\
\text { quality } \\
\text { control } \\
\end{array}$ & 4.5 & 13.50 & 3.10 \\
\hline $\begin{array}{l}\text { Study of physical } \\
\text { constants of sub- } \\
\text { stances (description, } \\
\text { solubility, melting } \\
\text { point, boiling point, } \\
\text { solidification, etc.) }\end{array}$ & $\begin{array}{l}\text { Non-compliance with } \\
\text { specifications } \\
\text { Use of non- } \\
\text { pharmacopoeial meth- } \\
\text { ods and tests }\end{array}$ & 4.5 & $\begin{array}{l}\text { Personnel er- } \\
\text { rors, equipment } \\
\text { failure }\end{array}$ & 2 & $\begin{array}{l}\text { Monitoring, } \\
\text { calibration } \\
\text { of equip- } \\
\text { ment, } \\
\text { substance } \\
\text { quality } \\
\text { control }\end{array}$ & 4.5 & 40.50 & 9.29 \\
\hline $\begin{array}{l}\text { Study of physico- } \\
\text { chemical properties } \\
\text { of substances (spe- } \\
\text { cific optical rotation, } \\
\text { characteristics of UV } \\
\text { and IR spectra, } \\
\text { chromatographic } \\
\text { properties, etc.) }\end{array}$ & $\begin{array}{l}\text { Non-compliance with } \\
\text { specifications } \\
\text { Use of pharmacopoeial } \\
\text { methods and tests }\end{array}$ & 4.5 & $\begin{array}{l}\text { Personnel er- } \\
\text { rors, equipment } \\
\text { failure }\end{array}$ & 2 & $\begin{array}{l}\text { Monitoring, } \\
\text { calibration } \\
\text { of equip- } \\
\text { ment, } \\
\text { substance } \\
\text { quality } \\
\text { control }\end{array}$ & 3 & 27.00 & 6.19 \\
\hline
\end{tabular}


Continuation of Table 1

\begin{tabular}{|c|c|c|c|c|c|c|c|c|}
\hline 1 & 2 & 3 & 4 & 5 & 6 & 7 & 8 & 9 \\
\hline $\begin{array}{l}\text { Study of physico- } \\
\text { chemical properties } \\
\text { of substances (spe- } \\
\text { cific optical rota- } \\
\text { tion, nature of UV } \\
\text { and IR spectra, } \\
\text { chromatographic } \\
\text { properties, etc.) }\end{array}$ & $\begin{array}{l}\text { Non-compliance with } \\
\text { specifications } \\
\text { Use of non- } \\
\text { pharmacopoeial meth- } \\
\text { ods and tests }\end{array}$ & 4.75 & $\begin{array}{l}\text { Personnel er- } \\
\text { rors, equipment } \\
\text { failure }\end{array}$ & 3 & $\begin{array}{c}\text { Monitoring, } \\
\text { calibration } \\
\text { of equip- } \\
\text { ment, } \\
\text { substance } \\
\text { quality } \\
\text { control }\end{array}$ & 3 & 42.75 & 9.80 \\
\hline \multicolumn{9}{|c|}{ Estimates of purity and quantitative content of potential BAS } \\
\hline $\begin{array}{l}\text { Determination of } \\
\text { total impuritie }\end{array}$ & $\begin{array}{l}\text { Use of pharmacopoeial } \\
\text { methods and tests }\end{array}$ & 3 & $\begin{array}{l}\text { Personnel er- } \\
\text { rors, equipment } \\
\text { failure }\end{array}$ & 2 & $\begin{array}{l}\text { Monitoring, } \\
\text { substance } \\
\text { quality } \\
\text { control } \\
\end{array}$ & 3.5 & 21.00 & 4.81 \\
\hline $\begin{array}{l}\text { Determination of } \\
\text { concomitant impu- } \\
\text { rities }\end{array}$ & $\begin{array}{l}\text { Use of pharmacopoeial } \\
\text { methods and tests }\end{array}$ & 3 & $\begin{array}{l}\text { Personnel er- } \\
\text { rors, equipment } \\
\text { failure }\end{array}$ & 1 & $\begin{array}{l}\text { Monitoring, } \\
\text { substance } \\
\text { quality } \\
\text { control } \\
\end{array}$ & 2 & 6.00 & 1.28 \\
\hline $\begin{array}{l}\text { Quantitative deter- } \\
\text { mination of BAS } \\
\text { content by chemical } \\
\text { methods }\end{array}$ & $\begin{array}{l}\text { Use of pharmacopoeial } \\
\text { methods and tests }\end{array}$ & 3.25 & $\begin{array}{l}\text { Personnel er- } \\
\text { rors, equipment } \\
\text { failure }\end{array}$ & 1 & $\begin{array}{l}\text { Monitoring, } \\
\text { substance } \\
\text { quality } \\
\text { control } \\
\end{array}$ & 3 & 9.75 & 2.24 \\
\hline $\begin{array}{l}\text { Quantitative deter- } \\
\text { mination of BAS } \\
\text { content by chemical } \\
\text { methods }\end{array}$ & $\begin{array}{l}\text { Use of non- } \\
\text { pharmacopoeial meth- } \\
\text { ods and tests }\end{array}$ & 4.25 & $\begin{array}{l}\text { Personnel er- } \\
\text { rors, equipment } \\
\text { failure }\end{array}$ & 2 & $\begin{array}{l}\text { Monitoring, } \\
\text { substance } \\
\text { quality } \\
\text { control }\end{array}$ & 3.5 & 29.75 & 6.82 \\
\hline $\begin{array}{l}\text { Determination of } \\
\text { the quantitative } \\
\text { content of BAS by } \\
\text { physical and chem- } \\
\text { ical methods }\end{array}$ & $\begin{array}{l}\text { Use of pharmacopoeial } \\
\text { methods and tests }\end{array}$ & 4.5 & $\begin{array}{l}\text { Personnel er- } \\
\text { rors, equipment } \\
\text { failure }\end{array}$ & 1 & $\begin{array}{l}\text { Monitoring, } \\
\text { calibration } \\
\text { of equip- } \\
\text { ment }\end{array}$ & 3.5 & 15.75 & 3.61 \\
\hline $\begin{array}{l}\text { Determination of } \\
\text { the quantitative } \\
\text { content of BAS by } \\
\text { physical and chem- } \\
\text { ical methods } \\
\end{array}$ & $\begin{array}{l}\text { Use of non- } \\
\text { pharmacopoeial meth- } \\
\text { ods and tests }\end{array}$ & 5 & $\begin{array}{l}\text { Personnel er- } \\
\text { rors, equipment } \\
\text { failure }\end{array}$ & 2 & $\begin{array}{l}\text { Monitoring, } \\
\text { calibration } \\
\text { of equip- } \\
\text { ment }\end{array}$ & 3.5 & 35.00 & 8.02 \\
\hline Total & & & & & & & 453.05 & \\
\hline
\end{tabular}

\section{Research results}

The creation of new biologically active substances begins with the selection of promising active ingredients that exhibit certain pharmacological properties and/or may subsequently have greater activity than their predecessors and a smaller number of side effects. Inventors in the field of synthesis of new active compounds are con- stantly developing new and improving existing methods of synthesis. For the further transfer of any technique, a necessary condition is its patent protection.

The transfer of the synthesis technique is accompanied by a number of risks, which depend on many factors and can be represented in the form of a diagram (Fig. 1).

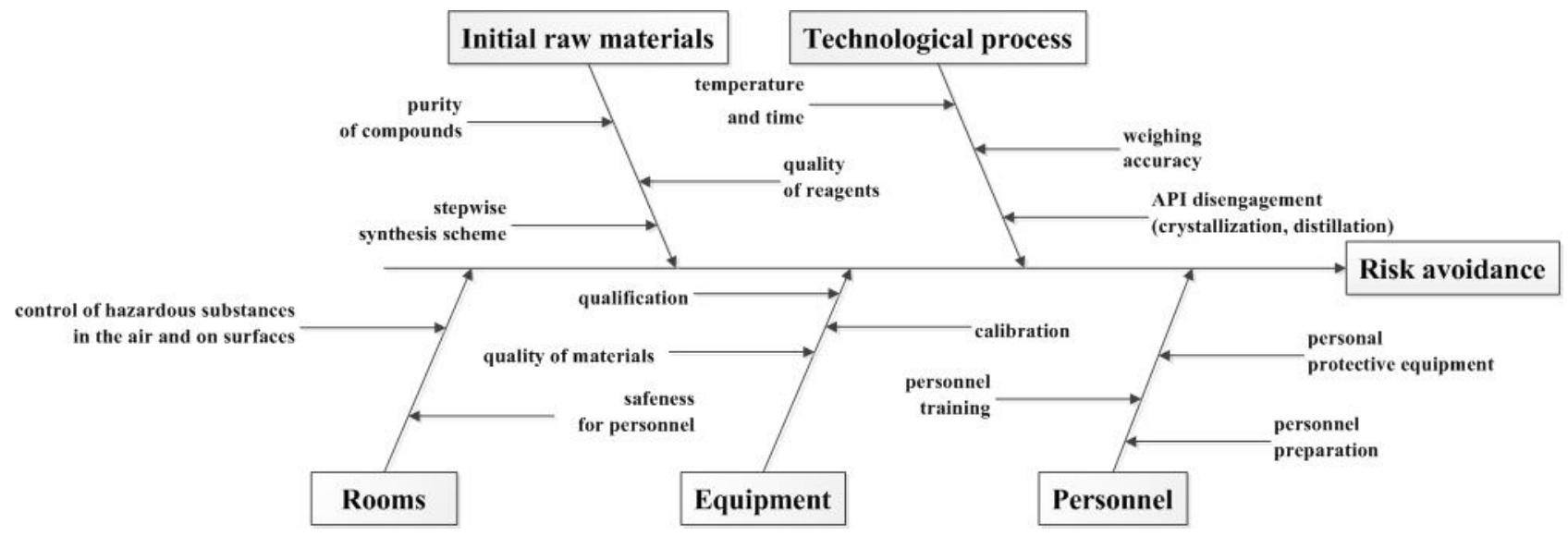

Fig. 1. Diagram of the analysis of the root causes of risks when scaling the synthesis technique 
For active compounds selected for preclinical and clinical trials, the improvement of the transfer of the synthesis technique requires the standardization of both the technological process and the active biological substance. For this purpose, there is a need to develop methods for quality control of the active compound according to the relevant indicators using pharmacopoeial/nonpharmacopoeial methods of analysis [12, 13]. The development of MQC is carried out with the introduction of appropriate changes and standards and taking into account the risks that arise when scaling the method of synthesis of the active substance, and from the obtained indicators form a "quality certificate" (Fig. 2).

The ranking of the priority risk number was carried out depending on the number of stages of the synthesis technique and the use for standardization of the obtained biologically active compound with pharmacopoeial/nonpharmacopoeial methods of analysis (Table 2).

\begin{tabular}{|c|c|c|}
\hline \multirow{2}{*}{\multicolumn{2}{|c|}{$\begin{array}{c}\text { Substance quality certificate (project) } \\
\text { The name of the substance }\end{array}$}} & \\
\hline & & \\
\hline \multicolumn{2}{|c|}{ Gross formula $\quad$ Molecular weight } & \\
\hline \multicolumn{3}{|c|}{ Quality control methods according to which tests are conducted } \\
\hline Indicator & Requirements of regulatory documentation & Methods of conducting \\
\hline Decription & $\begin{array}{l}\text { Indicate the characteristics of the physical condition and color of } \\
\text { the substance. If necessary, provide information on odor and } \\
\text { hygroscopicity. (Indicators may change with the change in the } \\
\text { scheme of obtaining the substance) }\end{array}$ & $\mathrm{EP} / \mathrm{SPhU} 5.11$ \\
\hline \multicolumn{3}{|l|}{ Solubility } \\
\hline Identification & $\begin{array}{l}\text { Combinations of infrared spectroscopy, electron } \\
\text { spectrophotometry or chromatography (gas, liquid or thin } \\
\text { layer) with characteristic chemical reactions are used to } \\
\text { identify substances. }\end{array}$ & \\
\hline $\begin{array}{c}\text { Melting point *. } \\
\text { Boiling point/ } \\
\text { distillation temperature } \\
\text { limits **. } \\
\text { Relative density ** } \\
\text { Refractive index ** } \\
\text { Viscosity ** }\end{array}$ & $\begin{array}{l}\text { * Tests are commonly used to characterize solids. } \\
\text { ** These tests are administered to characterize liquid } \\
\text { substances. }\end{array}$ & $\mathrm{EP} / \mathrm{SPhU}$ 2.2.5-2.2.18 \\
\hline $\begin{array}{l}\text { Accompanying } \\
\text { impurities }\end{array}$ & $\begin{array}{l}\text { Impurities that are starting / intermediate products and } \\
\text { the content exceeds } 0.05 \% \text { must be identified and } \\
\text { normalized, impurities with a content of less than } 0.05 \% \\
\text { are normalized in the amount of unidentified impurities. } \\
\text { Therefore, when changing the synthesis scheme and } \\
\text { when scaling, the substance must be controlled for } \\
\text { impurities. }\end{array}$ & $\mathrm{EP} / \mathrm{SPhU} 5.10$ \\
\hline $\begin{array}{c}\text { Residual amount of } \\
\text { organic solvents }\end{array}$ & $\begin{array}{l}\text { It is necessary to provide information on all solvents } \\
\text { used in the production of the substance and to control } \\
\text { their residual amount. }\end{array}$ & EP / SPhU 2.4.24, 5.4 \\
\hline Inorganic impurities & $\begin{array}{l}\text { The regulation of their content aims to further distinguish } \\
\text { of the registered technology from the new scalable, } \\
\text { depending on the equipment used and additional } \\
\text { solvents / reagents, water quality. }\end{array}$ & $\mathrm{EP} / \mathrm{SPhU} 2.4$ \\
\hline $\begin{array}{l}\text { Weight loss on drying } \\
\text { or Water }\end{array}$ & $\begin{array}{l}\text { Added to control the content of volatile substances and / } \\
\text { or moisture in the substance. The introduction of one of } \\
\text { these tests with content rationing is usually mandatory. }\end{array}$ & $\begin{array}{l}\mathrm{EP} / \mathrm{SPhU} 2.2 .32 \\
\text { or } \\
\mathrm{EP} / \mathrm{SPhU} 2.5 .12\end{array}$ \\
\hline $\begin{array}{c}\text { Quantitative } \\
\text { determination }\end{array}$ & $\begin{array}{l}\text { To quantify the basic component in the substance, it is } \\
\text { desirable to use direct methods of analysis. For salts, it is } \\
\text { usually sufficient to analyze only one of the ions - } \\
\text { preferably pharmacologically active. Note the copper } \\
\text { content as the main component in the substance (usually } \\
\text { in terms of dry or anhydrous substance). If necessary, } \\
\text { determine the biological activity. }\end{array}$ & $\mathrm{EP} / \mathrm{SPhU} 2.5$ \\
\hline
\end{tabular}

Fig. 2. The structure of the "quality certificate" of the active compound after scaling the synthesis technique 
Priority risk number of taking into account different stages of scaling the methodology

\begin{tabular}{|l|c|c|}
\hline $\begin{array}{c}\text { Dependence of PRN on the number of stages of the method of synthesis and use for standardi- } \\
\text { zation of BAS pharmacopoeial/non-pharmacopoeial methods of analysis }\end{array}$ & PRN $_{\text {st. }}$ & $\begin{array}{c}\text { PRN }_{\text {st. }} \\
\boldsymbol{\%}^{\circ}\end{array}$ \\
\hline One-stage scheme of synthesis using pharmacopoeial methods of analysis & 98.63 & 21.77 \\
\hline One-stage scheme of synthesis using non-pharmacopoeial methods of analysis & 153.63 & 33.91 \\
\hline Two-stage scheme of synthesis using pharmacopoeial methods of analysis & 105.50 & 22.29 \\
\hline Two-stage scheme of synthesis using non-pharmacopoeial methods of analysis & 160.50 & 35.43 \\
\hline Multi-stage synthesis scheme using pharmacopoeial methods of analysis & 131.13 & 28.94 \\
\hline Multi-stage synthesis scheme using non-pharmacopoeial methods of analysis & 193.00 & 42.60 \\
\hline
\end{tabular}

\section{Discussion of research results}

Laboratory synthesis techniques can be scaled to pilot and/or industrial sites [18]. The creation of a pilot site leads to additional costs that can be eliminated by transferring the synthesis technique to enterprises engaged in the synthesis of substances and equipment in both pilot and industrial facilities in accordance with GMP requirements [19]. The transfer of the synthesis technique to the pilot/industrial site is accompanied by the risks of replacing laboratory equipment with industrial equipment, which can lead to changes in the physicochemical properties of the compound, the appearance of new impurities, affect the yield of the substance and so on. All this should be taken into account when standardizing a new active substance.

Improving the method of synthesis in the laboratory in order to reduce the number of stages leads to risks such as additional costs due to the replacement of reagents and equipment upgrades [20-22]. The calculated percentage of PRN (9.93\%) (Table 1) of BAS synthesis using a multi-stage technique indicates that under production conditions, the risks of obtaining the substance in one or two stages are insignificant.

Improving the synthesis technique in production conditions requires the use of other starting and intermediate products of synthesis, reagents, solvents, technological parameters, etc. (PRN is $32.87 \%$, Table 1) and can lead to risks such as obtaining isomeric products, polymorphic forms of substances, other impurities, which, in turn, may affect some physicochemical properties and yield of the final compound. These risks should be mitigated by developing methods of quality control (MQC). MQC allows to control not only the technological process, but also to standardize the test compound, to study its stability and to determine the shelf life of the active substance. When compiling the MQC, it should be borne in mind that the physicochemical properties of the substance obtained under industrial conditions must coincide with the properties of the compound that has passed the initial pharmacological tests.

MQC, on the basis of which the quality certificate for the finished product is formed (Fig. 2), is developed in accordance with the requirements of the general article of SPhU "Substances for pharmaceutical use" and contains information on the physicochemical properties of the substance to which the active compound must correspond throughout the "life cycle". Typically, the quality certificate for the finished product is developed in the quality control departments of the enterprise where the scales of the synthesis of the compound, the laboratories of which are equipped with equipment for pharmacopoe- ial analysis. In the case of using non-pharmacopoeial methods of analysis there are risks of using additional equipment (calculated PRN is $32.67 \%$ ).

Quality control methods should include the following indicators: empirical name of the compound in the national language and Latin, structural formula of the substance, gross formula, molecular weight, properties, identification methods, purity tests, quantification, conditions and shelf life (Fig. 2).

The empirical name of the compound contains general information about the main structural features of the molecule (heterocyclic system, functional groups, their positions, etc.). The structural formula of the substance is proved after the synthesis of the compound and during the transfer of the method it is sufficient to confirm it by the method of mass chromatographic analysis or X-ray diffraction.

Improving the method of synthesis of the compound during scaling can lead to minor changes in the physical properties of the substance, which is reflected in the section of MQC (monograph) - Description. The appearance of the substance is partly informative about the method of synthesis (replacement of solvent and conditions of crystallization of the compound), which can lead to changes in the shape of crystals, the formation of polymorphic forms of the compound, which may further affect the bioavailability of the active substance. To avoid the risk of altering the appearance of a synthetically derived substance, the MQC should indicate the method of preparation of the compound.

Pharmacopoeial requirements for the use of solvents with a wide polarity, such as water, ethyl alcohol, acetone, methylene chloride, hexane, are used in the development of the MQC for the Solubility test as an additional characteristic of identity and purity testing, avoiding the use of flammable or highly toxic.

Identification of a new compound according to pharmacopoeial requirements is carried out using a set of tests confirming the physical constants and physicochemical properties of the active substance. Depending on the physical state of the substance, the definition of physical constants such as melting point, boiling point, pour point, etc. is used for identification, which allows to conclude the identity of the substance and predict the presence of impurities (for example, expanding the melting temperature range may indicate the presence of organic impurities).

To identify the active compound, it is desirable to use a set of physicochemical methods that confirm the structure and properties of the substance. Mandatory pharmacopoeial methods for the identification of an organic compound are methods of absorption spectrophotometry in the 
infrared, ultraviolet and visible regions. In the case of chromatographic methods, the determination of $\mathrm{pH}$ or angle of rotation/specific optical rotation, the identification of the compound is combined with purity tests. Chemical methods are used depending on the presence of characteristic functional groups in the molecule of the active substance, in the case of salts - acid residues and prefer the general ones included in section 2.3 of SPhU "Identification" or to distinguish the test compound from analogues in structure.

To quantify the compounds, a suitable confirmatory method is selected, which allows the substance to be determined, preferably by a pharmacologically active part of the molecule. The reliability and accuracy of the methods of identification, testing for purity and determination of the quantitative content of the compound is proved by studying the validation characteristics according to the requirements of the pharmacopoeia [12-14, 23].

When developing the MQC under the section "Tests for purity" should be borne in mind that at all stages of scaling the synthesis technique there are risks due to the appearance of new impurities, which throughout the life of API should be tested for quality and especially quantity, as they can significantly affect safety of substances [13, 24].

The risks of impurities in the scaling of laboratory methods of synthesis are associated with such factors as (Table 1):

- number of synthesis stages;

- concentration and purity of starting and intermediate products of the chemical reaction;
- purity of solvents and reagents used in the synthesis;

- purification of the synthesized compound (recrystallization, sublimation, etc.);

- class and quality of equipment;

- quality of cleaning of premises and equipment after preliminary synthesis;

- room air purification.

The purity of the starting and intermediate products of the chemical reaction depends not only on the amount of accompanying impurities, but also impurities of inorganic and organic nature.

The synthesis of any compound in the laboratory differs from industrial by the use of various equipment (class, quality, components). When the method of synthesis is transferred to production, the equipment changes and there is a risk of impurities such as heavy metals, acidity or alkalinity and others. All these impurities are determined using pharmacopoeial methods $[25,26]$.

The chemical process depends on such parameters as the concentration and rate of addition of reagents, the temperature and time of the reaction, the amount of solvent, the presence of a catalyst, the $\mathrm{pH}$ level. Features of the synthesis of the compound using other reagents or reagents of another purity class can lead to changes in the content of inorganic and organic impurities and the amount of organic solvents. Substantiation of the nature and content of inorganic impurities must be carried out based on the source of these impurities in the substance (equipment, reagents, etc.) (Fig. 3).

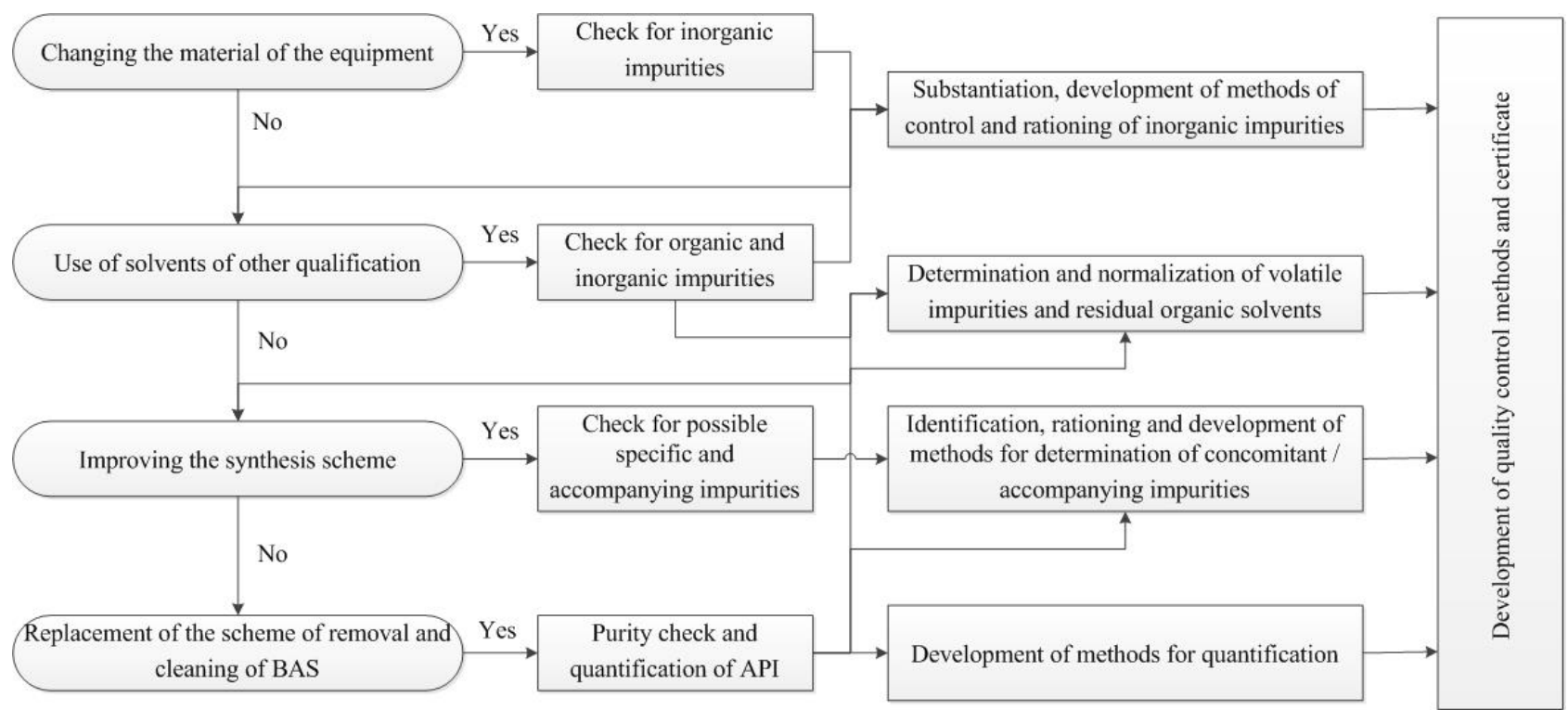

Fig. 3. Identification of risks of impurities when scaling the synthesis technique

The replacement of solvents is reflected in the features of the determination of volatile substances in API, which affect not only the physicochemical and microbiological properties of drugs, but also the toxicity of the substance. To avoid the toxic effects of residual amounts of organic solvents, it is advisable to use low-toxic solvents in the synthesis of BAS, such as solvents of class 3 [12].

When developing a standard working method (SWM), MQC, registration dossier or draft monographs, volatile and concomitant substances should be quantified in the case of mass balance API purity. According to the ICH guidelines, individual API impurities (identified and unidentified) and their sum should be monitored in the preparations [27, 28].

Chromatographic methods such as thin layer, liquid and gas chromatography are most often used to determine concomitant impurities and residual amounts of organic solvents. The methods described in pharmaco- 
poeias can also be used to determine the content of these impurities. The manufacturer may select the most appropriate validated analytical techniques for use in any particular case to determine concomitant impurities and residual amounts of solvents.

Based on the listed risks associated with the occurrence of impurities, a scheme of the process of pre- venting the appearance of impurities during scaling of the synthesis of a new active substance (should be controlled as total inorganic impurities, concomitant impurities, potential technological impurities and API degradation products). Usually for impurities, the content of which is normalized above $0.1 \%$, it is necessary to decipher their structure [12, 29] (Fig. 4).

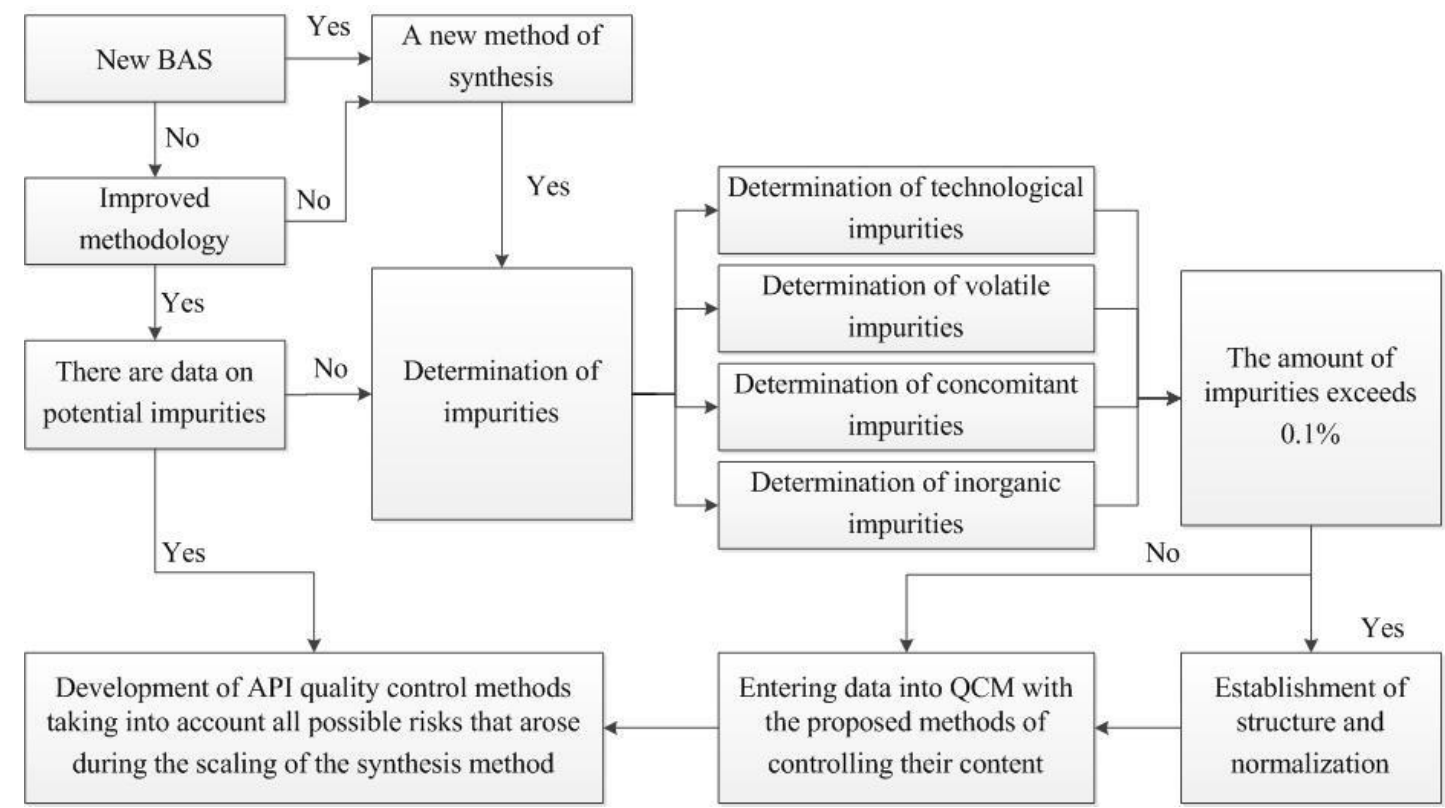

Fig. 4. Scheme of the process of preventing the appearance of impurities during scaling of the BAS synthesis technique

When developing methods for quality control of the compound obtained by the method of synthesis, which was subjected to scaling, it is necessary to take into account the requirements of $\mathrm{ICH}, \mathrm{SPhU}$ and GMP on the features of standardization of substances using pharmacopoeial/non-pharmacopoeial methods of analysis $[3,12,30]$.

Study limitations. Studied algorithms for the occurrence and prevention of quality risks during the scaling of synthesis methods may vary in each case depending on the number of stages of synthesis, equipment of industrial sites, staff qualifications, equipment certification, etc.

Prospects for further research. The use of the proposed algorithm for the emergence of quality risks arising from the scaling of synthesis methods by scientists engaged in the search for potential active substances, employees of enterprises on the basis of which scaling of synthesis methods, and laboratories for standardization of pharmaceutical products.

\section{Conclusions}

The stages of scaling the method of synthesis of a potential active compound for transfer to clinical and preclinical trials are determined and the approach to standardization of the substance obtained by the proposed method is substantiated. The calculated absolute and relative values of the priority numbers of risks indicate that the most identified risks are associated with multistage synthesis, which leads to an increase in the number of concomitant impurities, and the use of informal quality control techniques in standardizing a new compound. Thus, when developing quality control methods for a new active substance, it is necessary to take into account all the risks that may arise during the transfer of the synthesis method to the industrial site and make appropriate tests during the standardization of the compound according to pharmacopoeial and international requirements.

\section{Conflict of interest}

The authors declare that they have no conflicts of interest.

\section{References}

1. Bevz, N., Mishchenko, V. (2019). Development of a design research for determining the quality indicators of potential API. 1. newly synthesized substances for primary pharmacological screening. ScienceRise: Pharmaceutical Science, 5 (21), 18-26. doi: http://doi.org/10.15587/2519-4852.2019.182279

2. Pro derzhavne rehuliuvannia diialnosti u sferi transferu tekhnolohii (2006). Zakon Ukrainy No. 143-V. 14.09.2006. Available at: https://zakon.rada.gov.ua/laws/show/143-16

3. McDonald, K., Ho, K. (2012). ICH Q11: development and manufacture of drug substances-chemical and biotechnological/biological entities. Generics and Biosimilars Initiative Journal, 1 (3-4), 142-144. doi: http://doi.org/10.5639/gabij.2012.0103-4.025

4. Pro likarski zasoby (1996). Zakon Ukrainy No. 123/96-VR. 04.04.1996. Available at: http://zakon.rada.gov.ua /laws/main/123/96-\%D0\%B2\%D1\%80

5. Quality assurance of pharmaceuticals. A compendium of guidelines and related materials. Vol. 2. Good manufacturing practices and inspection (2007). Geneva: World Health Organization, 46. 
6. DSTU ISO 9000:2015. Systemy upravlinnia yakistiu. Osnovni polozhennia ta slovnyk terminiv (ISO 9000:2015, IDT) (2016). Kyiv: Derzhspozhyvstandart Ukrainy, 45.

7. Levin, M. (2005). Pharmaceutical Process Scale-Up. Drugs and the pharmaceutical sciences. Marcel Dekker, Inc., 588.

8. Sobolieva, T. O. (2008). Upravlinnia formuvanniam ta realizatsiieiu innovatsiinoho potentsialu pidpryiemstva (za materialamy farmatsevtychnykh pidpryiemstv Ukrainy). Kyiv, 20.

9. Raval, N., Tambe, V., Maheshwari, R., Deb, P. K., Tekade, R. K. (2018). Scale-Up Studies in Pharmaceutical Products Development. Dosage Form Design Considerations, 669-700. doi: http://doi.org/10.1016/b978-0-12-814423-7.00019-8

10. Shanley, A. (2019). Scaling Up Right the First Time. Pharmaceutical Technology Europe, 31 (9), 10-14

11. Plane, G. (2018). Managing Process Scale-Up and Tech Transfer. Available at: https://www.merckmillipore.com/ GB/en/20151116_192332?IdOfReferringPage=20150727_145042\&Pname=108

12. Derzhavna Farmakopeia Ukrainy. Vol. 1. (2015). Kharkiv: Derzhavne pidpryiemstvo «Ukrainskyi naukovyi farmakopeinyi tsentr yakosti likarskykh zasobiv», 1128.

13. The European Pharmacopoeia (2018). European Directorate for the Quality of Medicines \& HealthCare of the Council of Europe. Strasbourg, 6. Available at: http://online6.edqm.eu/ep900/

14. The United States Pharmacopoeia, 41 - NF 36 (2018). The United States Pharmacopeial Convention. Rockville. Available at: https://opac.kku.ac.th/catalog/BibItem.aspx?BibID=b00420302

15. EMA/CHMP/CVMP/QWP/BWP/70278/2012-Rev 1 (2014). Guideline on process validation for finished products - information and data to be provided in regulatory submissions.

16. Liapunov, M., Bezuhla, O., Soloviov, O. et. al. (2012). Standartyzatsiia farmatsevtychnoi produktsii. Kharkiv: Morion, 728.

17. Vetiutneva, N. O., Ubohov, S. H., Pylypchuk, L. B., Fedorova, L. O., Todorova, V. I., Budnikova, T. M. et. al. (2014). Suchasnyi stan ta tendentsii rozvytku normatyvno-pravovoho rehuliuvannia u sferi zabezpechennia yakosti likarskykh zasobiv. Farmatsevtychnyi zhurnal, 3, 66-74.

18. Nor, A. M. Pilot plant scale up techniques contents: introduction on pilot plant and scale up. Available at: https://www.academia.edu/8939649/PILOT_PLANT_SCALE_UP_TECHNIQUES_CONTENTS_INTRODUCTION_ON_PILOT_ PLANT_AND_SCALE_UP

19. Felton, L. A. (2011). Pharmaceutical Process Scale-Up, 3rd edition. Drug Development and Industrial Pharmacy, 38 (4), 512-512. doi: http://doi.org/10.3109/03639045.2011.633523

20. Lehmann, H., LaVecchia, L. (2010). Scale-Up of Organic Reactions in a Pharmaceutical Kilo-Lab Using a Commercial Microwave Reactor. Organic Process Research \& Development, 14 (3), 650-656. doi: http://doi.org/10.1021/op900269y

21. Tiberghien, A. C., von Bulow, C., Barry, C., Ge, H., Noti, C., Collet Leiris, F. et. al. (2018). Scale-up Synthesis of Tesirine. Organic Process Research \& Development, 22 (9), 1241-1256. doi: http://doi.org/10.1021/acs.oprd.8b00205

22. Gołofit, T., Maksimowski, P., Szwarc, P., Cegłowski, T., Jefimczyk, J. (2017). Scale-Up Synthesis of Hexabenzylhexaazaisowurtzitane, an Intermediate in CL-20 Synthesis. Organic Process Research \& Development, 21 (7), 987-991. doi: http://doi.org/10.1021/acs.oprd.7b00101

23. Guidance for industry: Q8 (R2) pharmaceutical development (2009). US FOOD AND DRUG ADMINISTRATION. Center for Drug Evaluation and Research: Silver Spring.

24. Nogueira, R., Queiroz, S. M., Silva, G. E. B., Rocha, W. F. C., Sarmanho, G. F., Almeida, R. R. R., Moreira, G. F. (2012). Determination of volatiles in pharmaceutical certified reference materials. Journal of the Brazilian Chemical Society, 23 (9), 1636-1646. doi: http://doi.org/10.1590/s0103-50532012005000021

25. ICH Harmonized Tripartite Guideline: Q3A (R2) Impurities in new substances (2016). The international conference on harmonisation of technical requirements for registration of pharmaceuticals for human use (ICH), 15 .

26. ICH Harmonized Tripartite Guideline: Q3B (R2) Impurities in new drug products (2006). The international conference on harmonisation of technical requirements for registration of pharmaceuticals for human use (ICH), 14 .

27. Ibrahim, M. M. (2015). Investigation on thermal stability and purity determination of two antihypertensive drugs, valsartan and losartan potassium. International Journal of Current Pharmaceutical Research, 7 (3), 64-69.

28. Bevz, O. V., Ukrainets, I. V., Vashchenko, O. V., Georgiyants, V. A., Budianska, L. V. (2018). Obtaining of the pharmacopoeial reference sample of the mandelic acid isopropyl ester. Visnik Farmaciï, 1 (93), 3-11. doi: http://doi.org/10.24959/nphj.18.2196

29. WHO Expert Committee on Specifications for Pharmaceutical Preparations. Forty- first report (2007). WHO Technical Report Series, No. 943. Geneva: World Health Organization.

30. Quality assurance of pharmaceuticals. A compendium of guidelines and related materials. Vol. 2. Second updated edition. Good manufacturing practices and inspection. Geneva: World Health Organization, 46.

Received date 20.11.2020

Accepted date 24.12.2020

Published date 30.12.2020

Nataliia Bevz, PhD, Associate Professor, Department of Pharmaceutical Chemistry, National University of Pharmacy, Pushkinska str., 53, Kharkiv, Ukraine, 61002

E-mail: natali.bevz.60@gmail.com

Volodymyr Mishchenko, PhD, Associate Professor, Department of Quality, Standardization and Certification of Medicines, National University of Pharmacy, Pushkinska str., 53, Kharkiv, Ukraine, 61002 E-mail: Mivlan64@gmail.com

Viktor Khomenko, Doctor of Pharmaceutical Sciences, Professor, Head of Department, Department of Pharmacy and Pharmacology, Donetsk National Medical University, Pryvokzalna str., 27, Lyman, Ukraine, 84404 E-mail: khomenko_donnmu@ukr.net

Victoriya Georgiyants, Doctor of Pharmaceutical Sciences, Professor, Head of Department, Department of Pharmaceutical Chemistry, National University of Pharmacy, Pushkinska str., 53, Kharkiv, Ukraine, 61002 